\title{
A TREE GIANT
}

RON JENSEN, 849 10th Street Northeast, Swift Current, Saskatchewan. $\mathrm{S} 9 \mathrm{H} 2 \mathrm{~T} 5$

The tree is a giant by any standard. It is a Laurel-leaved or Bayleaved Willow (Salix pentandra). This particular tree sits along the shore of Slearwater Lake near Kyle, Saskatchewan. The species is not native to Canada. It is a "Eurasian species, introduced and planted as an ornamental" according to Budd's Flora of the Canadian Prairie Provinces. A short paragraph on the species describes it as a small tree not over 7 $\mathrm{m}$ tall. The single specimen described in this articles was measured at $22 \mathrm{~m}$ tall. The trunk girth and diameter are equally overwhelming at $5.56 \mathrm{~m}$ and $1.77 \mathrm{~m}$ respectively.

Staff at the Prairie Farm Rehabilitation Administration (PFRA) Tree

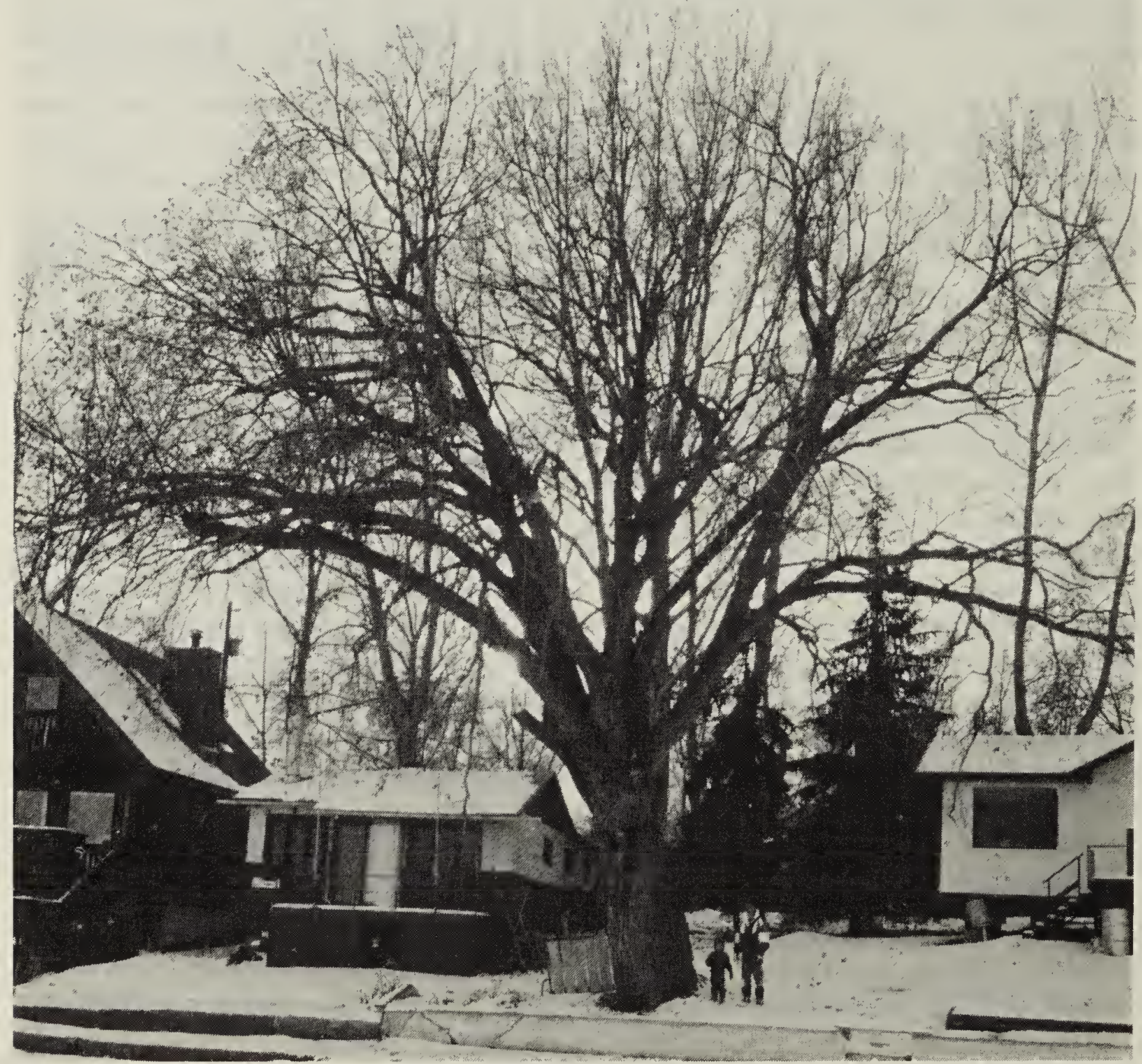

Giant willow (22 m tall) at Clearwater Lake, Saskatchewan

Ron Jensen 
Nursery who identified samples of winter twigs and leaves indicated 10 $\mathrm{m}$ tall would be considered above average height for the species.

According to Gordon Nelson of Kyle, his father, Elmer Nelson, the landowner, planted the tree in 1925 , before Clearwater Lake became a Regional Park. As you may note from the picture, the tree grows very close to the lake edge now surrounded by vacation cabins. The source of the tree is unknown but the PFRA Tree Nursery at Indian Head was sending trees out for planting prior to 1925. Gordon Nelson cannot remember the size of the tree when it was planted. If a sapling of three years was planted, it is now nearly 65 years old. I could not find any information on longevity of this willow species, however, PFRA staff indicated that 65 years is old for this species of willow. Its size and age without doubt say something about the preferred habitat of the Laurelleaved Willow.

To give an idea of scale, the two people in the picture, taken $21 \mathrm{De}$ cember 1991, are my son Jeffrey (1 $\mathrm{m}$ tall) and nephew Brad Tyberg (1.8 $m$ tall), both of Swift Current.

\section{ADDITIONS TO THE FLORA OF CYPRESS HILLS PROVINCIAL PARK WEST BLOCK IN SOUTH- WESTERN SASKATCHEWAN}

\section{BERNARD DE VRIES, George F. Ledingham Herbarium, University of}

Regina, Regina, Saskatchewan. S4S OA2

The Cypress Hills are situated in the arid short-grass prairie in southwestern Saskatchewan, forming a high plateau on the plains of western Canada. The elevation of the plateau ranges from 870 to $1350 \mathrm{~m}$ and is bisected by a major valley, called the "Gap." The plateau consists of two parts, the centre block and the west block. The Cypress Hills are of interest because they support a rich and varied flora of montane and boreal species. Above $1300 \mathrm{~m}$ a coniferous forest occurs, similar to that in the southern Rocky Mountains.

In 1990, a study was designed to survey proposed logging areas in the centre and west blocks of the park, in order to assess the status of rare and endangered plants, their critical habitat and potential means for their preservation. This article documents three vascular and two non-vascular species new to the flora of the west block that were found during the study.

The earliest botanical reports for the Cypress Hills were made by John Macoun between 1880 and 1892. ${ }^{6}$ Breitung, Ledingham (pers. comm., 1991), de Vries and others have undertaken more recent floristic studies. ${ }^{2,3,4,5,7}$ 